\title{
Root Growth and Recovery in Temperate Broad-Leaved Forest Stands Differing in Tree Species Diversity
}

\author{
Catharina Meinen, Dietrich Hertel, and Christoph Leuschner*
}

Plant Ecology, University of Göttingen, Untere Karspüle 2, D-37073 Göttingen, Germany

\begin{abstract}
In contrast to studies on aboveground processes, the effect of species diversity on belowground productivity and fine-root regrowth after disturbance is still poorly studied in forests. In 12 oldgrowth broad-leaved forest stands, we tested the hypotheses that (i) the productivity and recovery rate (regrowth per standing biomass) of the fineroot system (root diameter $<2 \mathrm{~mm}$ ) increase with increasing tree species diversity, and that (ii) the seasonality of fine-root biomass and necromass is more pronounced in pure than in tree species-rich stands as a consequence of non-synchronous root biomass peaks of the different species. We investigated stands with 1,3 , and 5 dominant tree species growing under similar soil and climate conditions for changes in fine-root biomass and necromass during a 12-month period and estimated fine-root productivity with two independent approaches (ingrowth cores, sequential coring). According to the analysis of 360 ingrowth cores, fine-root growth into the root-free soil increased with tree species diversity from $72 \mathrm{~g} \mathrm{~m}^{-2} \mathrm{y}^{-1}$ in the monospecific plots to $166 \mathrm{~g} \mathrm{~m}^{-2} \mathrm{y}^{-1}$ in the 5 -species
\end{abstract}

plots, indicating an enhanced recovery rate of the root system after soil disturbance with increasing species diversity $\left(0.26,0.34\right.$, and $0.51 \mathrm{y}^{-1}$ in $1-, 3-$, and 5 -species plots, respectively). Fine-root productivity as approximated by the sequential coring data also indicated a roughly threefold increase from the monospecific to the 5 -species stand. We found no indication of a more pronounced seasonality of fine-root mass in species-poor as compared to species-rich stands. We conclude that species identification on the fine root level, as conducted here, may open new perspectives on tree species effects on root system dynamics. Our study produced first evidence in support of the hypothesis that the fine-root systems of more diverse forest stands are more productive and recover more rapidly after soil disturbance than that of species-poor forests.

Key words: Acer; Carpinus; Fagus; fine-root biomass; fine-root phenology; fine-root production; Fraxinus; ingrowth cores; sequential coring; Tilia.

Received 3 September 2008; accepted 22 June 2009; published online 14 October 2009

Author Contributions: C. Meinen conducted field and laboratory work, data evaluation; D. Hertel conceived the study design, data evaluation, writing; Ch. Leuschner contributed by research idea, study design, writing. *Corresponding author; e-mail: cleusch@gwdg.de

\section{INTRODUCTION}

Only recently, research on the functions of biodiversity has shifted its focus from grassland and herbaceous communities to forests (Scherer-Lorenzen and others 2007). Experiments in synthetic grasslands have shown that increasing plant species 
diversity can enhance aboveground productivity, may increase the resilience of the community after disturbance, and can affect other functions of the ecosystem (Tilman and others 1996, 1997, 2001; Peterson and others 1998; Hector and others 1999; Tilman 1999; Chapin and others 2000; Hector 2001; Loreau and Hector 2001). Much less is known about the functions of tree diversity in forests. Most of the existing studies on diversity effects in forests dealt with monocultures and two-species mixtures (Kelty 1992; Bartelink and Olsthoorn 1999); these trials produced contradictory results (Pretzsch 2005). In addition, most of these studies investigated aboveground responses, whereas much less is known about effects of tree diversity on belowground processes such as root growth and turnover.

Although tree fine roots $(<2 \mathrm{~mm}$ in diameter) represent only a minor part of total tree biomass, it has been suggested that they can consume up to $30-50 \%$ of the annual primary production (Vogt and others 1996; Ruess and others 1996; Xiao and others 2003). Fine roots are not only responsible for water and nutrient uptake, but they are also an important component of the forest carbon cycle (for example, DeAngelis and others 1981; Fitter 1996). In the vast majority of studies in mixed forests, fine roots have been investigated without species determination, but the ability to distinguish between species is crucial for detecting tree diversity and tree species effects in the fine-root systems of forests. To our knowledge, there exist only a few studies in mixed forests that used a determination key for distinguishing fine roots of different tree species (Hertel 1999; Hölscher and others 2002; Korn 2004).

Fine-root productivity can be measured with different methods, but the results depend strongly on the employed technique with lower values estimated with ingrowth cores and higher values calculated with sequential coring or minirhizotron approaches (McClaugherty and others 1982; Aber and others 1985; Nadelhoffer and Raich 1992; Makkonen and Helmisaari 1999; Hertel and Leuschner 2002; Hendricks and others 2006). Fine-root growth into root-free ingrowth cores has frequently been used as a simple method to estimate fine-root production in forests (for example, Persson 1979, 1983; Vogt and others 1998; Makkonen and Helmisaari 1999; Jentschke and others 2001). However, the manipulation of growth conditions (for example, root injury during installation, no competition processes, disturbed soil) may lead to biased results on root productivity (Hertel and Leuschner 2002). Therefore, fine-root growth into the ingrowth cores may be a more accurate estimate of the root recolonization potential after soil disturbance than for fine-root production under ambient soil conditions. Another technique that is often used for root production estimates is minirhizotrons (for example, Andren and others 1991; Majdi 1996; Johnson and others 2001). This method is considered to track fine-root dynamics more reliably than soil cores (Trumbore and Gaudinski 2003; Hendricks and others 2006), but it does not allow species determination in mixed stands. Sequential coring is a commonly used, but often problematic and labor-intensive method for estimating fine-root productivity that allows species identification at the fine root level (Hölscher and others 2002) and thus has certain advantages when mixed stands are studied. It additionally provides information about seasonal changes in fine-root mass and hence on differences in fineroot phenology among the co-occurring tree species.

This study investigated fine-root biomass and its dynamics in temperate broad-leaved forests differing in tree species diversity. By comparing oldgrowth forests with one, three, or five dominant tree species, we aimed at detecting effects of tree species diversity or tree species identity on fine-root biomass, necromass, root mass phenology and root productivity. We employed two different approaches for estimating fine-root productivity, the ingrowth core and the sequential coring approach, which both enabled species identification on the basis of fine roots. Moreover, the ingrowth core data were interpreted as a measure of root system recovery after soil disturbance.

By measuring the seasonality in fine-root biomass and necromass in each plot with 1,3 , and 5 species and by quantifying fine-root growth dynamics (in each four plots per diversity level), we tested the hypotheses that (i) seasonal changes in fine-root mass are more pronounced in pure than in tree species-rich stands as a consequence of nonsynchronous root mass peaks of the different tree species during the growing season, and that (ii) productivity and regrowth rate of the fine-root system after disturbance increase with increasing tree species diversity.

\section{Materials AND Methods}

\section{Study Site}

The Hainich National Park in Thuringia (Germany) protects one of the largest continuous broad-leaved forest areas in Central Europe. The forest is mainly dominated by European beech (Fagus sylvatica L.), 
but in some parts, up to 14 tree species coexist, which is a consequence of contrasting forest management strategies in the past. We conducted the study in mature deciduous broad-leaved forest stands in the north-east of the National Park. In total, 12 study plots $(50 \times 50 \mathrm{~m})$ were selected that cover a gradient from low to high tree species diversity. Plots of diversity level 1 (DL 1) contained mainly F. sylvatica ( $>95 \%$ of total basal area). Plots of diversity level 2 (DL 2) were built by Fagus s., Tilia sp. (T. cordata Mill. and T. platyphyllos Scop.) and Fraxinus excelsior L. The study plots of diversity level 3 (DL 3) were formed by Fagus s., Tilia sp., Fraxinus e., Carpinus betulus L. and Acer sp. (A. pseudoplatanus L. and A. platanoides L.). Additional rare tree species were Acer campestre L., Prunus avium L., Quercus petraea Liebl., Sorbus torminalis (L.) Crantz and Ulmus glabra L. A detailed description of the selection criteria for the study plots is given in Leuschner and others (2009). Four study plots per diversity level were selected as replicates within an area of approximately $12 \mathrm{~km}^{2}$ (mean minimum distance between the plots was $420 \mathrm{~m}$ ) on nearly ground level terrain at an elevation of approximately $350 \mathrm{~m}$ asl. Annual mean air temperature was about $7.5^{\circ} \mathrm{C}$ and annual precipitation averaged at $670 \mathrm{~mm}$ (data of the nearby weather station Weberstedt/Hainich). All study plots showed comparable soils derived from the same bedrock (Triassic limestone covered by Pleistocene loess). Hence, soil texture and the thickness of the mineral soil above the bedrock were principally similar.

The selected plots represented mature forest stands with a closed canopy. Mean tree age was about 100 years; however, the Fagus trees in the DL 1 plots were older (146 years on average). The basal areas were similar between plots, but stem densities were somewhat higher on the plots of DL 2 (Table 1). Canopy height ranged from $26 \mathrm{~m}$ in plots of DL 3 to $38 \mathrm{~m}$ in plots of DL 1. The Shannon index increased from 0.2 in the almost monospecific beech plots to 1.8 in the DL 3 plots. Mean fineroot biomass $(0-20 \mathrm{~cm})$ ranged from $280 \mathrm{~g} \mathrm{~m}^{-2}$ in the DL 1 plots to $366 \mathrm{~g} \mathrm{~m}^{-2}$ in the DL 2 plots and did not differ significantly between the three different diversity levels (Meinen and others 2009). The soil type of the plots was a Luvisol (IUSS Working Group WRB 2006) with stagnic properties in spring and winter and a dry period in summer (Figure 1). In the foliation period from mid-May to November, the soil temperature at $5 \mathrm{~cm}$ soil depth was $1{ }^{\circ} \mathrm{C}$ higher at the DL 3 plots than at the DL 1 plots. Mineral soil bulk density increased with increasing soil depth from $1.1 \mathrm{~g} \mathrm{~cm}^{-3}$ in $0-10 \mathrm{~cm}$ (identical mean for plots of the three diversity levels) to 1.4 (DL 1 plots), 1.5 (DL 2 plots), and $1.3 \mathrm{~g} \mathrm{~cm}^{-3}$ (DL 3 plots) in $20-30 \mathrm{~cm}$ soil depth (Guckland and others 2009). The soil texture (mineral soil at $0-30 \mathrm{~cm}$ ) was rich in silt (ca. 82, 72 , and $70 \%$ in the DL 1, DL 2, and DL 3 plots), but poor in sand $(<5 \%$ in all plots of the three diversity levels). The $\mathrm{pH}\left(\mathrm{H}_{2} \mathrm{O}\right)$ value in $0-10 \mathrm{~cm}$ soil depth ranged from 4.6 in the DL 1 plots to 6.7 in the DL 3 plots. Hence, base saturation was particularly low in the DL 1 plots. Soil organic carbon stocks in the upper mineral soil were not significantly different among the DL 1, DL 2, and DL 3 plots, but DL 1 plots showed a markedly higher C/ $\mathrm{N}$ ratio in this soil layer than DL 2 and DL 3 plots (ca. 17 vs. ca. $14 \mathrm{~g}^{-1}$ ). In contrast, DL 1 plots had somewhat lower SOC stocks in the lower mineral soil layers than the DL 2 and DL 3 plots, but no significant differences in the $\mathrm{C} / \mathrm{N}$ ratio among the plots of the three diversity levels existed in the subsoil (Guckland and others 2009). Although the DL 1 plots included a thin ectorganic litter layer of up to $4 \mathrm{~cm}$ depth (mean $1.5 \mathrm{~cm}$ ) atop the mineral soil, no permanent organic layer was present in the DL 2 and DL 3 plots. Because the soils of all stands were derived from the same geological parent material, the marked differences in soil chemical properties between DL 1 plots and DL 2 and DL 3 plots are most likely to a large extent caused by the capability of beech to acidify the soil with its ligninrich leaf litter of low decomposability (for example, Hagen-Thorn and others 2004; Vesterdal and others 2008). No significant differences in soil properties were apparent between DL 2 and DL 3 plots, which mostly consist of tree species with more rapidly decomposing leaf litter.

In all plots, mean daily soil temperature at $5 \mathrm{~cm}$ soil depth was monitored by nine temperature data loggers (DS 1921 Thermochron iButtons, Fa. Dallas Semiconductor, USA) per plot.

\section{Fine-Root Sampling}

A basic inventory of the standing fine-root biomass at the 12 plots of the three diversity levels was done in the years 2005 and 2006 at 24 sampling locations per plot (Meinen and others 2009). The 24 soil coring locations per plot were randomly distributed within each stand and were representative for the different tree species combinations occurring in the plots. Soil samples were taken with a $3.5 \mathrm{~cm}$ diameter soil corer from the upper $20 \mathrm{~cm}$ of the soil (including the organic litter layer if present). The fine-root biomass of the samples was extracted as described below and the data were used to analyze differences in fine-root system size among the 12 plots (Meinen and others 


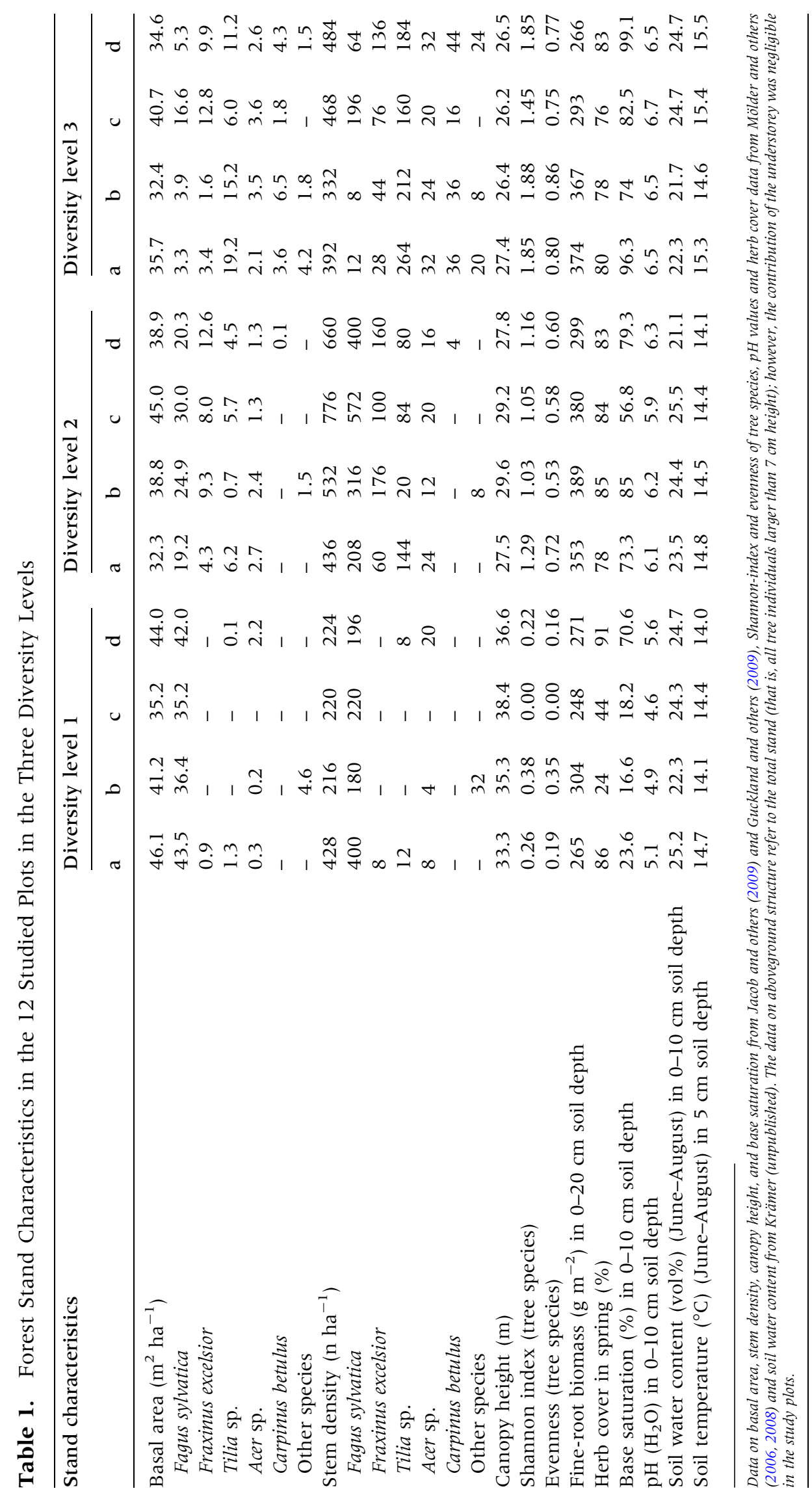




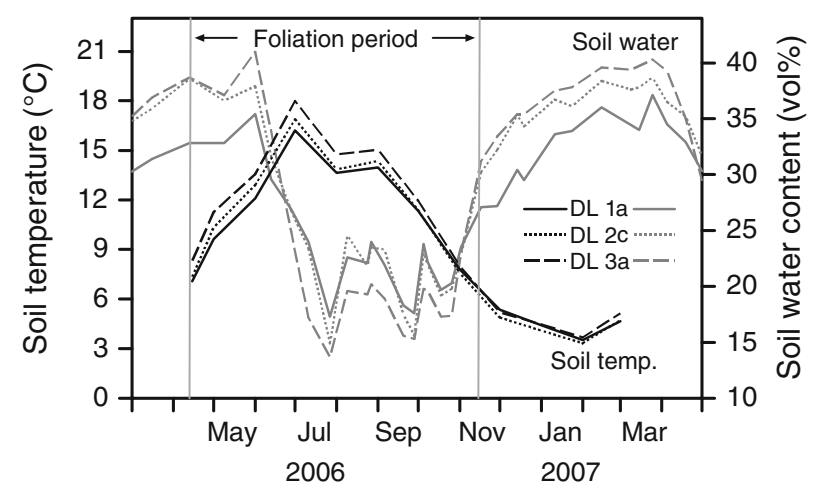

Figure 1. Seasonal course of soil temperature at $5 \mathrm{~cm}$ soil depth and volumetric soil water content at $10 \mathrm{~cm}$ soil depth from April 2006 until February 2007 in the plots DL 1a, DL 2c and DL 3a. Given are daily means of nine temperature logger stations and means of six volumetric soil water content (Sentek) readings per plot (every second week).

2009). The standing fine-root biomass recorded from this inventory is given in Table 1 ; it was used as a reference for calculating the fine-root recovery rate (ingrowth per standing biomass) in the ingrowth core approach (see below).

To record seasonal changes in fine-root bio- and necromass, a sequential coring campaign was conducted from April 2006 until January 2007. Due to the time-consuming work of fine-root sorting, we had to focus on one plot per diversity level, that is, three plots in total (DL la, DL 2c and DL 3a). Hence, generalization of the results obtained with this method is hampered. We took cores in spring (April 21, 2006), summer (June 28, 2006), autumn (September 27, 2006) and winter (January 15, 2007). This sampling design was consistent to the inventory design described above. Each soil core was divided into two sub-samples: 0$10 \mathrm{~cm}$ (including the organic layer if present) and $10-20 \mathrm{~cm}$. To extract the fine roots from the soil, the samples were soaked shortly in water and the fine roots were washed out using a sieve (mesh size $0.25 \mathrm{~mm}$ ). Fine roots longer than $10 \mathrm{~mm}$ were picked out by hand with a pair of tweezers and separated under a stereomicroscope into the live and the dead fraction and were sorted according to species. Live and dead fine roots were distinguished by root elasticity, color, and the degree of the cohesion of stele and periderm (Persson 1978; Leuschner and others 2001). Root death was indicated by a complete loss of stele and cortex, a dark cortex or stele, or a white, but non-turgid stele. Morphological characteristics like the surface structure, color of the periderm, type of mycorrhi- zal infection and ramification pattern were applied for species identification according to an identification key established for the occurring tree species by Hertel (1999), Hölscher and others (2002) and Korn (2004). Grass and herb roots were distinguished from tree roots by their smaller diameter, non-lignified structure and lighter color. The fineroot fraction larger than $10 \mathrm{~mm}$ represents the major part of the living fine-root mass, but dead fine roots are often smaller due to progressive decay. A method introduced by van Praag and others (1988) and modified by Hertel (1999) was applied to one-sixth of all samples after extraction of fine roots larger than $10 \mathrm{~mm}$ in length. The soil residues were evenly distributed on a large sheet of filter paper $\left(730 \mathrm{~cm}^{2}\right)$ subdivided into 36 squares. Six of these squares were randomly selected and the soil material was analyzed for even the smallest fineroot fragments under the stereomicroscope. However, these small root fragments could not be sorted by tree species. The dry mass of small dead rootlets was extrapolated to the entire sample by means of the ratio of small dead rootlets to large dead roots (>10 mm length) that was established in a subsample for each occurring species. The sorted fineroot biomass and necromass was dried at $70^{\circ} \mathrm{C}$ for $48 \mathrm{~h}$ and weighed. Fine-root mass was expressed as root abundance (unit: $\mathrm{g} \mathrm{m}^{-2}$ ).

Fine-root production was estimated with the 'minimum-maximum method' by using the sequential coring data (Persson 1978; McClaugherty and others 1982). This method equates the difference between the minimum and the maximum of total fine-root mass (sum of fine-root bioand necromass) with the fine-root production in the measured period. The coring was conducted on four occasions within an 8-month period by assuming that no root mass peak occurred between the sampling dates. In principal, only significant differences between seasonal root mass peaks and lows should be considered when applying the minimum-maximum approach. Significant minimum-maximum differences were found only in a minority of cases (about 1/3). We assumed that a zero production of beech roots in the DL 1 plot is an unrealistic result and therefore we accepted the non-significant differences in root mass in the DL 1 plot as well. For other tree species in the mixed DL 2 and DL 3 plots, a zero production was similarly unlikely; thus we calculated the production with the non-significant differences in these cases as well. We are well aware that this procedure might lead to partly biased estimates of fine-root production. 
Ingrowth cores were applied as a second method for estimating fine-root productivity in the 12 plots (Persson 1980; Powell and Day 1991; Majdi 1996). This approach quantifies the ingrowth of fine roots into root-free soil. We interpreted the fine-root regrowth (given as $\mathrm{g} \mathrm{m}^{-2} \mathrm{y}^{-1}$ ) not only as a measure of fine-root production, but also as an estimate of the recovery of the fine-root system after disturbance because this parameter quantifies the velocity at which fine roots re-explore empty soil volume after the initial cut off of the roots. In May 2005, 30 ingrowth cores per plot were installed at random locations and resampled after 24 month in May 2007. Soil cores were extracted from the topsoil down to $20 \mathrm{~cm}$ depth with a sharp soil corer (diameter $3.5 \mathrm{~cm}$ ), the soil material was cleaned by hand from all macroscopically visible live and dead rootlets and the cores were replaced into the hole. The minimum distance between two ingrowth cores was $1 \mathrm{~m}$. The edges were marked accurately at the soil surface. The structure and density of the extracted soil was conserved as much as possible. To minimize soil disturbance no mesh bags were used. We observed fine-root growth in 2-month intervals by harvesting single ingrowth cores to determine the beginning of fineroot growth into the cores. These data indicate that fine-root growth started in the bulk of the ingrowth cores around May 2006, that is, after a 12month lag period. We harvested all cores in May 2007 and calculated fine-root growth into the cores by quantifying the dry mass of larger (>10 mm length) root segments (living and dead) as described above. We calculated the fine-root recovery rate $\left(\mathrm{y}^{-1}\right)$ of the different tree species in the ingrowth cores by relating annual fine-root regrowth into the ingrowth cores to standing fineroot biomass in undisturbed soil in the plots recorded in close vicinity to the ingrowth cores (Meinen and others 2009; Table 1).

\section{Statistical Analyses}

The Shapiro and Wilk test was used to analyze all data sets for normal distribution. Fine-root mass data sets from the sequential coring approach showed non-normal distributions and remained skewed even after log or root transformation. Therefore, the data sets were tested by KruskalWallis single factor analysis of variance followed by a non-parametric Mann-Whitney two sample $U$ test to detect significant differences in total fineroot mass between different sampling dates. The ingrowth core data sets showed normal distribution and were tested for significant differences between diversity levels by an ANOVA procedure followed by a Scheffé $f$-test. All analyses were accomplished at a $5 \%$ rejection level. The software package SAS, version 8.2 (SAS Institute Inc., Cary, NC, USA), was used for the analyses.

The dependence of tree fine-root production (sequential coring data) on the Shannon-index of the tree species and on standing fine-root biomass was analyzed with a Spearman rank correlation analysis (using SAS software). The dependence of tree and herb fine-root regrowth in the ingrowth cores on Shannon-index and evenness of the tree species, total fine-root biomass of the stands, base saturation, $\mathrm{pH}$ of the soil, soil water content and soil temperature was analyzed by single factor linear regression analyses (software package Xact version 8.03, SciLab, Hamburg, Germany). Data on diversity indices (Shannon-index and evenness) of the stands were obtained from Mölder and others (2008).

\section{Results \\ Seasonal Variability of Fine-Root Biomass and Necromass}

The seasonal variability of fine-root biomass in the three studied plots DL la, DL 2c, and DL 3a was low in the period of April 2006 to January 2007. The seasonal biomass maxima and minima differed by not more than $20 \%$ in this 9 -month period if the stand totals (all species) were considered (Figure 2). Biomass minima were recorded in all plots in April 2006, maxima in June 2006 (DL 2c and DL 3a) or in January 2007 (DL la). Mean fine-root biomass of the stands was higher in the two mixed stands (DL 2c and DL 3a: $370 \mathrm{~g} \mathrm{~m}^{-2}$ ) than in the monospecific DL la plot $\left(265 \mathrm{~g} \mathrm{~m}^{-2}\right)$ in the period of the study. Our data indicate that the different species in the two mixed stands were different in their biomass seasonality with the asynchronous occurrence of maxima and minima. For example, fine-root biomass of Acer and Carpinus tended to be highest in April in the DL 3a plot, whereas Tilia reached its peak in June, Fagus in September, and Fraxinus in January. However, most of the seasonal differences were not significant but more tendencies.

In general, seasonality was more pronounced in fine-root necromass than in fine-root biomass. Seasonal minima and maxima of total fine-root necromass differed by about $40 \%$ in plot DL la, but by a factor of 3.6 in plot DL 2c. In all plots, fine-root necromass was significantly lower in January 2007 than at earlier sampling occasions. In the two 
Fine root biomass
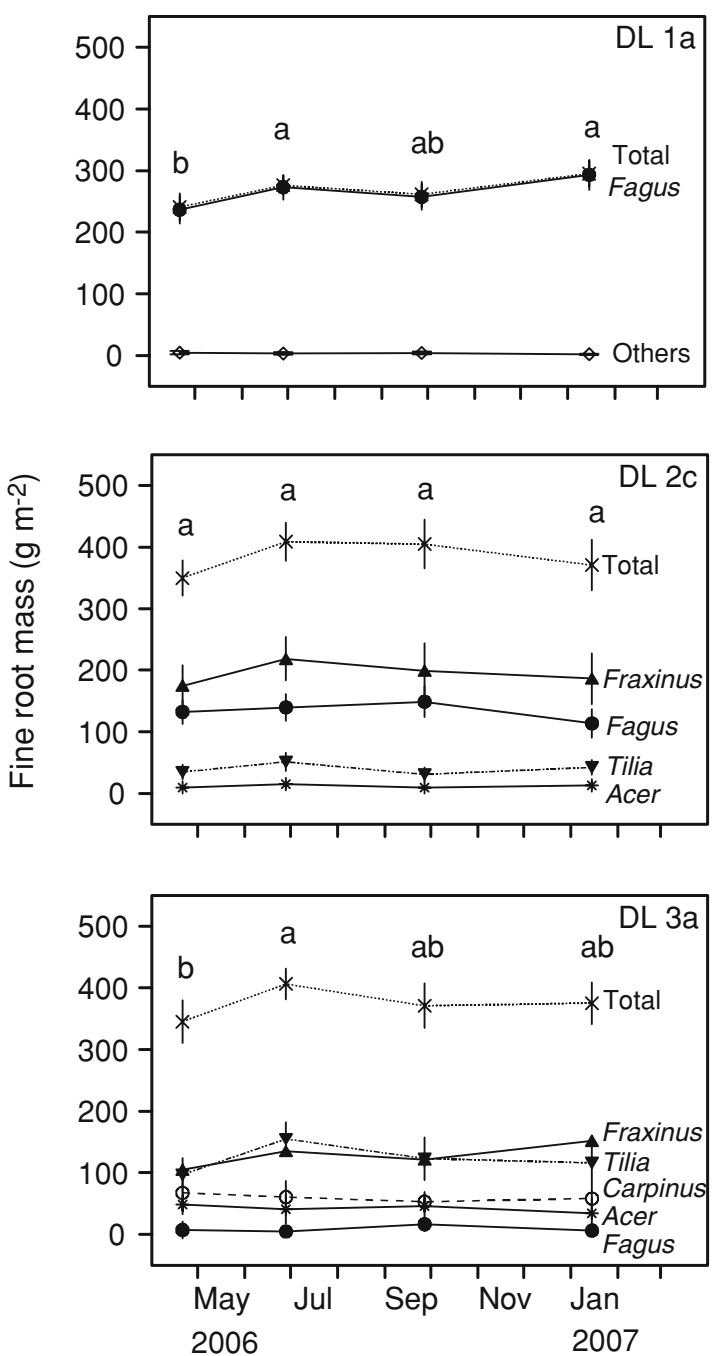

Fine root necromass
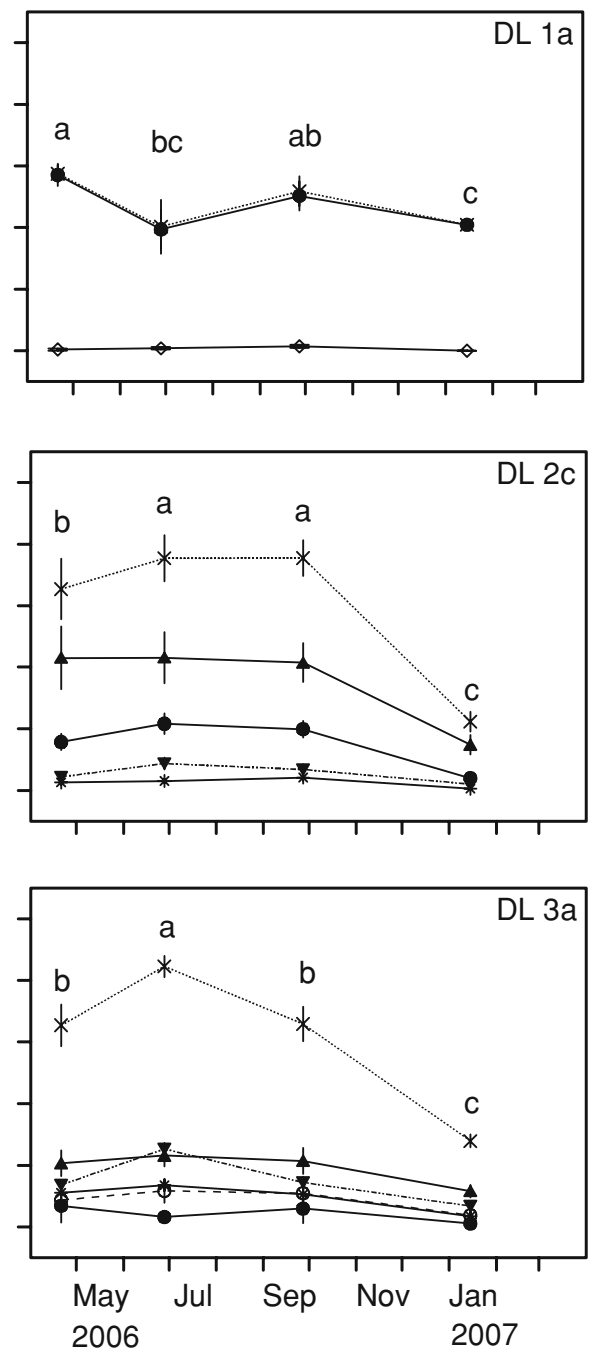

Figure 2. Seasonal variation in fine-root biomass and fine-root necromass at $0-20 \mathrm{~cm}$ soil depth in the DL $1 \mathrm{a}$, DL $2 \mathrm{c}$ and DL 3a plots. Given are means $( \pm 1 \mathrm{SE})$ of profile totals and of single tree species from 24 sampling locations per plot on four sampling dates (April 21, 2006, June 28, 2006, September 27, 2006, January 15, 2007). Different letters indicate significant differences of total fine-root biomass between sampling dates $(P<0.05)$.

mixed stands, the necromass of the species and also of the whole stand was highest in June and lowest in January. This indicates that seasonal minima and maxima occurred simultaneously in the plots of DL 2c and DL 3a. In contrast, in the DL la plot, the fine-root necromass of Fagus was highest in April and significantly lower in June and January.

\section{Fine-Root Production Estimated by Sequential Coring}

Fine-root production as estimated with the sequential coring procedure in the period April 2006 to January 2007 increased markedly with increasing tree species diversity, ranging from
$186 \mathrm{~g} \mathrm{~m}^{-2} \mathrm{y}^{-1}$ in the plot DL la to $564 \mathrm{~g} \mathrm{~m}^{-2} \mathrm{y}^{-1}$ in the DL 3a plot (Table 2). Results from a Spearman rank correlation analysis revealed that the fine-root production of the stands was not significantly affected by standing fine-root biomass, but strongly depended on tree-species diversity $(P<0.001)$.

In the mixed stands, $60-71 \%$ of total annual fine-root production occurred in the uppermost soil layer, whereas in the DL la plot, 54\% of the estimated total annual fine-root production took place in 10-20 cm soil depth. In the DL 2c plot, Fraxinus $\left(259 \mathrm{~g} \mathrm{~m}^{-2} \mathrm{y}^{-1}\right)$ was the most productive species in the entire soil profile followed by Fagus $\left(154 \mathrm{~g} \mathrm{~m}^{-2}\right.$ $\left.\mathrm{y}^{-1}\right)$; both species accounted for $82 \%$ of the total 
Table 2. Annual Fine-Root Production in 0-10, 10-20 and 0-20 cm Soil Depth as Calculated from Sequential Coring Data Using the Minimum-Maximum Approach for the DL 1a, DL 2c, and DL 3a Plots

\begin{tabular}{|c|c|c|c|c|c|c|c|c|c|}
\hline \multirow{2}{*}{$\begin{array}{l}\text { Diversity } \\
\text { level }\end{array}$} & \multirow{2}{*}{$\begin{array}{l}\text { Depth } \\
(\mathrm{cm})\end{array}$} & \multicolumn{7}{|c|}{ Annual fine-root production $\left(\mathrm{g} \mathrm{m}^{-2} \mathrm{y}^{-1}\right)$} & \multirow[t]{2}{*}{ Stand total } \\
\hline & & $\begin{array}{l}\text { Fagus } \\
\text { sylvatica }\end{array}$ & $\begin{array}{l}\text { Fraxinus } \\
\text { excelsior }\end{array}$ & Tilia sp. & Acer sp. & $\begin{array}{l}\text { Carpinus } \\
\text { betulus }\end{array}$ & $\begin{array}{l}\text { Other } \\
\text { species }\end{array}$ & Herbs & \\
\hline \multirow[t]{3}{*}{ DL la } & $0-10$ & 85.2 & & & & & & 8.3 & \\
\hline & $10-20$ & 101.0 & & & & & & & \\
\hline & $0-20$ & 186.2 & & & & & & & 186.2 \\
\hline \multirow[t]{3}{*}{ DL 2c } & $0-10$ & 98.2 & 201.7 & 39.1 & 21.4 & & & 3.3 & \\
\hline & $10-20$ & 55.5 & 57.0 & 22.9 & 8.3 & & & & \\
\hline & $0-20$ & 153.7 & 258.7 & 62.0 & 29.7 & & & & 504.1 \\
\hline \multirow[t]{3}{*}{ DL $3 a$} & $0-10$ & 40.9 & 62.4 & 99.5 & 76.3 & 33.2 & 27.2 & 11.3 & \\
\hline & $10-20$ & 23.9 & 37.5 & 75.4 & 39.7 & 30.1 & 17.7 & & \\
\hline & $0-20$ & 64.8 & 99.9 & 174.9 & 116.0 & 63.3 & 44.9 & & 563.8 \\
\hline
\end{tabular}

Given are the differences between maximum and minimum fine-root mass (bio-plus necromass) from four sampling occasions (April 21, 2006, June 28, 2006, September 27, 2006, January 15, 2007; $n=24$ sampling locations per plot and sampling date) for the occurring tree species and the stand totals. 'Other species' refers to annual fine-root production of the rare species Acer campestre, Prunus avium, Ulmus glabra, and Quercus petraea.

fine-root production in this plot. In the DL 3a plot, total annual fine-root production was mainly composed by contributions from Tilia $(31 \%)$, Acer $(21 \%)$ and Fraxinus (18\%). Herbs had only a minor part in fine-root production with $3-11 \mathrm{~g} \mathrm{~m}^{-2} \mathrm{y}^{-1}$ in all plots.

Calculation of annual fine-root turnover (that is, production per standing biomass) for the three stands revealed that the turnover increased from $0.70 \mathrm{y}^{-1}$ in the DL la plot to 1.33 and $1.51 \mathrm{y}^{-1}$ in the DL 2c and DL 3a plots, respectively.

\section{Fine-Root Production and Recovery Rate Estimated by Ingrowth Cores}

The fine-root biomass of trees and herbs grown into root-free soil increased with increasing tree species diversity (Figure 3). Tree fine-root growth increased significantly from $72 \mathrm{~g} \mathrm{~m}^{-2} \mathrm{y}^{-1}$ in the DL 1 plots to $166 \mathrm{~g} \mathrm{~m}^{-2} \mathrm{y}^{-1}$ in the DL 3 plots (Figure $3 \mathrm{~A})$. The ingrowth cores in the DL 2 plots were mainly colonized by Fagus $(48 \%$ of total) and Fraxinus $(41 \%)$ roots, whereas five tree species contributed to the ingrowth in the DL 3 plots. In these species-rich stands, $38 \%$ of total annual fineroot production was identified as Tilia roots, followed by Fraxinus (24\%) and Carpinus (14\%). Annual fine-root growth of herbs increased from $2 \mathrm{~g} \mathrm{~m}^{-2} \mathrm{y}^{-1}$ in the DL 1 plots to $9 \mathrm{~g} \mathrm{~m}^{-2} \mathrm{y}^{-1}$ in the DL 3 plots (Figure 3B). Although annual herb root growth was 4.5 times higher in DL 3 plots than DL 1 plots, this difference was only marginally significant at $P<0.1$ due to the large variation among the plots of a diversity level.

The fine-root recovery rate (fine-root growth into ingrowth cores expressed per unit standing
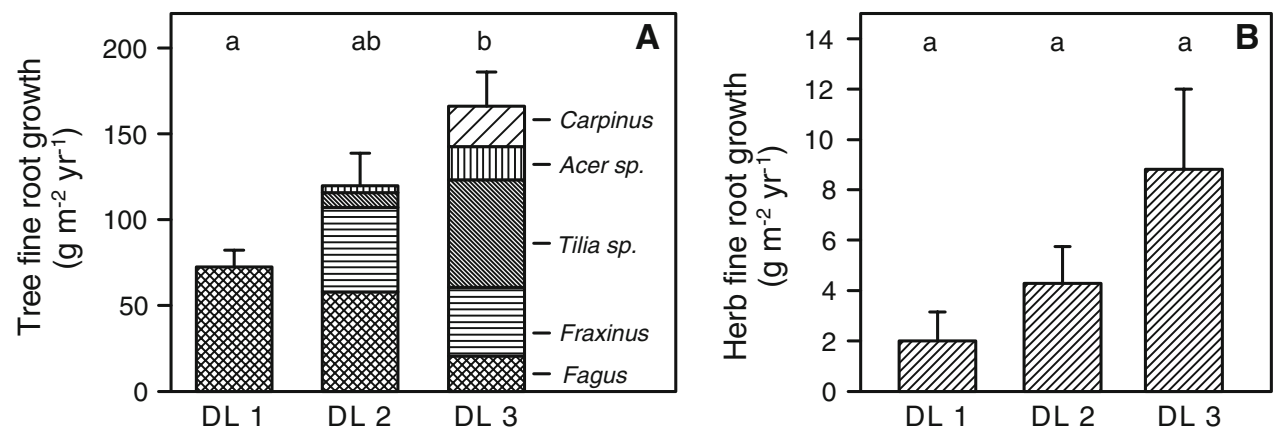

Figure 3. Fine-root growth of trees $(\mathbf{A})$ and herbs $(\mathbf{B})$ into root-free soil estimated with ingrowth cores in 12 plots of the three diversity levels. Given are means $( \pm 1 \mathrm{SE})$ for profile totals $(0-20 \mathrm{~cm})$ and tree species contribution in the four plot replicates per diversity level (approximately 20-30 sampling locations per plot). Different letters indicate significant differences between plots of the three diversity levels $(n=4)$ at $P<0.05$. Note different scales for tree and herb fine-root growth. 
Table 3. Fine-Root Recovery Rate in 0-20 cm Soil Depth as Estimated from the Ingrowth Core Data (Root Ingrowth per Time per Standing Fine-Root Biomass) of the Plots

\begin{tabular}{|c|c|c|c|c|c|c|c|}
\hline \multirow{2}{*}{$\begin{array}{l}\text { Diversity } \\
\text { level }\end{array}$} & \multirow{2}{*}{$\begin{array}{l}\text { Depth } \\
(\mathrm{cm})\end{array}$} & \multicolumn{6}{|c|}{ Fine-root recovery rate $\left(\mathrm{y}^{-1}\right)$} \\
\hline & & Fagus sylvatica & Fraxinus excelsior & Tilia sp. & Acer sp. & Carpinus betulus & Stand total \\
\hline DL 1 & $0-20$ & $0.26 \pm 0.03 \mathrm{a}$ & & & & & $.03 \mathrm{~A}$ \\
\hline DL 2 & $0-20$ & $0.47 \pm 0.17 \mathrm{a} \alpha$ & $0.37 \pm 0.07 \mathrm{a} \alpha$ & $0.16 \pm 0.08 \mathrm{a} \alpha$ & $0.18 \pm 0.07 \mathrm{a} \alpha$ & & $0.34 \pm 0.07 \mathrm{AB}$ \\
\hline DL 3 & $0-20$ & $0.85 \pm 0.54 \mathrm{a} \alpha$ & $0.35 \pm 0.06 \mathrm{a} \alpha$ & $0.63 \pm 0.10 \mathrm{~b} \alpha$ & $0.48 \pm 0.18 \mathrm{a} \alpha$ & $0.64 \pm 0.10 \alpha$ & $0.51 \pm 0.07 \mathrm{~B}$ \\
\hline
\end{tabular}

Means $\pm S E$ from four plot replicates per diversity level and 24 ingrowth core locations per plot. Different letters indicate significant differences between species (Greek letters) or diversity levels (Latin letters) at $P<0.05$.

Table 4. Correlation Coefficients for Linear Regressions Between Fine-Root Growth into Ingrowth Cores $(0-10 \mathrm{~cm}$ Soil Depth, $n=12)$ and Shannon Index, Evenness, Tree Fine-Root Biomass, Base Saturation, $\mathrm{pH}$ $\left(\mathrm{H}_{2} \mathrm{O}\right)$, Soil Water Content and Soil Temperature in $5 \mathrm{~cm}$ Soil Depth of the Respective Plots

\begin{tabular}{|c|c|c|c|c|c|c|}
\hline \multirow[t]{2}{*}{ Source } & \multicolumn{3}{|c|}{$\begin{array}{l}\text { Tree fine-root growth } \\
\left(\mathrm{g} \mathrm{m}^{-2} \mathrm{y}^{-1}\right)\end{array}$} & \multicolumn{3}{|c|}{$\begin{array}{l}\text { Herb fine-root growth } \\
\left(\mathrm{g} \mathrm{m}^{-2} \mathrm{y}^{-1}\right)\end{array}$} \\
\hline & $r$ & $r_{\mathrm{adj}}^{2}$ & $P$ & $r$ & $r_{\mathrm{adj}}^{2}$ & $P$ \\
\hline Shannon index (tree species) & 0.79 & 0.60 & $<0.001$ & 0.72 & 0.47 & $<\mathbf{0 . 0 1}$ \\
\hline Evenness (tree species) & 0.71 & 0.45 & $<0.01$ & 0.61 & 0.37 & $<\mathbf{0 . 0 1}$ \\
\hline Fine-root biomass ${ }^{1}$ & 0.39 & 0.07 & 0.10 & 0.17 & -0.07 & 0.30 \\
\hline Base saturation $^{1}$ & 0.71 & 0.46 & $<0.01$ & 0.62 & 0.33 & $<0.01$ \\
\hline $\mathrm{pH}\left(\mathrm{H}_{2} \mathrm{O}\right)^{1}$ & 0.75 & 0.52 & $<\mathbf{0 . 0 1}$ & 0.61 & 0.31 & $<0.05$ \\
\hline Soil water content ${ }^{1}$ (June-August) & -0.26 & -0.03 & 0.21 & -0.30 & -0.01 & 0.18 \\
\hline Soil water content ${ }^{1}$ (annual mean) & 0.29 & -0.01 & 0.19 & 0.17 & 0.07 & 0.30 \\
\hline Soil temperature (June-August) & 0.64 & 0.35 & $<0.01$ & 0.40 & 0.07 & 0.10 \\
\hline Soil temperature (annual mean) & 0.30 & -0.01 & 0.17 & 0.12 & -0.08 & 0.36 \\
\hline
\end{tabular}

fine-root biomass) of the stands significantly increased from $0.26 \mathrm{y}^{-1}$ in DL 1 plots to $0.51 \mathrm{y}^{-1}$ in the DL 3 plots (Table 3). This pattern was also found for the recovery rate of Fagus roots, which increased to an even greater extent from $0.26 \mathrm{y}^{-1}$ to $0.85 \mathrm{y}^{-1}$ with increasing tree species diversity, that is, from the monospecific to the mixed DL 3 stands. The recovery rate of Fraxinus did not differ between plots of DL 2 and DL 3, whereas for Tilia, a significant increase from $0.16 \mathrm{y}^{-1}$ (DL 2 plots) to $0.63 \mathrm{y}^{-1}$ (DL 3 plots) was found. The fine-root recovery rate of Acer also increased from the DL 2 plots to the DL 3 plots.

The ingrowth of tree and herb fine roots into the root-free soil cores was significantly correlated to a number of forest stand characteristics and edaphic parameters (Table 4). The strongest correlation was found between the Shannon-index of the tree species and the annual root growth of trees $(r=0.79 ; \quad P<0.001)$ and herbs $\quad(r=0.72$; $P<0.01)$. In contrast, standing fine-root biomass was neither related to tree root growth nor herb root growth into the ingrowth cores. However, the annual growth of tree and herb roots showed positive relationships with base saturation and soil $\mathrm{pH}$ $\left(\mathrm{H}_{2} \mathrm{O}\right)$, whereas no significant correlation was found with soil water content. Daily mean summer soil temperature at $5 \mathrm{~cm}$ soil depth showed a positive relationship only to the ingrowth of trees, not to that of herbs.

\section{Discussion}

\section{Seasonality of Fine-Root Biomass and Necromass}

Temperate tree species have been found to differ markedly in their phenologies of fine-root growth, 
resulting from different endogenous rhythms of carbon allocation to roots and contrasting root growth responses to temperature (Teskey and Hinckley 1981; Lyr and Garbe 1995; Lyr 1996). For example, maximum root growth of Fagus and Tilia was observed at $20^{\circ} \mathrm{C}$, whereas Carpinus revealed optimal root growth at higher temperatures (25$\left.30^{\circ} \mathrm{C}\right)$, Acer pseudoplatanus at lower temperatures $\left(15-20^{\circ} \mathrm{C}\right)$ (Lyr and Garbe 1995; Lyr 1996). Moreover, cold temperature seems to inhibit root growth of temperate tree species differently (Tryon and Chapin 1983; Steele and others 1997). Thus, we can expect that different fine-root growth rhythms overlay each other in mixed stands which should result in a less distinct seasonality of fine-root biomass in species-rich as compared to species-poor stands. In our study, the majority of tree species showed an increase in standing fine-root biomass from April to the end of June 2006, and a more or less constant biomass (or a slight decrease) through the autumn and winter 2006/2007. Even though we observed opposing seasonal biomass trends in certain coexisting species (for example, in Fraxinus and Tilia in stand DL 3a), seasonality of fine-root biomass was generally low on the species level and also on the stand level. Moreover, we found no indication of a more pronounced biomass seasonality in the monospecific beech stands (DL la) as compared to the mixed DL 2c and DL 3a stands. In general, there was a root biomass increase from April to the end of June (which was significant in the DL la and DL 3a plots) and a more or less constant biomass during summer, autumn and also winter. This is astonishing because soil temperature at $5 \mathrm{~cm}$ depth varied between 19.6 and $0.4^{\circ} \mathrm{C}$ over the year and soil moisture reached minima during dry periods at the end of July 2006. Thus, neither drought nor winter temperature resulted in a significant decrease of standing fine-root biomass in the Hainich forest. Low seasonal variations in fineroot biomass have also been reported from other temperate and boreal forests, for example, in Scots pine stands in Scandinavia (Persson 1978, 1983; Makkonen and Helmisaari 1998). On the other hand, McClaugherty and others (1982) and Vogt and others (1981) observed one or more distinct fine-root biomass peaks in temperate North American forests.

In our study, seasonality was generally more pronounced in fine-root necromass than in fineroot biomass in all plots. Necromass increased during summer and decreased strongly during winter in the mixed DL 2 and DL 3 plots, whereas it reached a peak in April and September and decreased only slightly during the winter in the beech-dominated DL 1 plot. In contrast to our results from the mixed plots, Konôpka and others (2006) and McClaugherty and others (1982) found that the amount of necromass was larger at the beginning and the end of the growing season than in mid-summer. Like in our study, Hertel (1999) found a fine-root necromass accumulation during summer in four beech forests. Necromass peaks in summer or autumn may result from elevated root mortalities (for example, Hendrick and Pregitzer 1993), or reduced root decomposition rates, both induced by summer droughts.

In the absence of fine-root decomposition data, we can only speculate about the fate of root necromass, which disappeared during the observation period. In our study, fine-root necromass decreased by $51-71 \%$ in the mixed DL 2 and DL 3 plots from the September to the April sampling date which points to a rapid fine-root decomposition even during autumn and winter. Similar to leaf litter (Jacob and others 2009), fine roots were found to decompose faster in the mixed plots. Very rapid fine-root decomposition was also observed in a minirhizotron study, in which the majority of birch and maple fine roots that died during the winter disappeared completely in April and showed a median decomposition period of 35 days (Tierney and others 2001). Joslin and Henderson (1987) determined an annual fine-root decomposition rate of $30-35 \%$ in a mixed hardwood forest, whereas fine roots of Norway spruce (Gaul and others 2008), sugar maple and white pine (McClaugherty and others 1982, 1984) decomposed with mass losses of $12-26 \%$ per year. Fine-root decay processes are investigated almost exclusively with litterbags (Silver and Miya 2001). Estimations from two studies using an 'intact-core' technique, however, revealed $10-23 \%$ greater annual mass losses, indicating an under-estimation of fine-root decomposition by the litterbag method (Dornbush and others 2001; Gaul and others, unpublished data).

The more rapid fine-root decomposition in the DL $2 \mathrm{c}$ and DL 3a plots in autumn and winter, as inferred from the pronounced necromass decrease, may be explained by the higher $\mathrm{pH}$ values and higher base saturation of the soil in these plots, which should favor root decomposition. In their literature review on global patterns of root decomposition, Silver and Miya (2001) concluded that the chemical composition of the root tissue (mainly Ca concentration and $\mathrm{C} / \mathrm{N}$ ratio) influences root decay more than abiotic factors (for example, temperature or soil moisture). The chemical composition of the root tissue is known to depend lar- 
gely on soil chemical properties (King and others 1997; Silver and Miya 2001). In the present study, not only the higher soil $\mathrm{pH}$ and base saturation in the DL 2 and DL 3 stands should have caused a root chemical composition more favorable for rapid root decay, but the change in tree species composition from beech to species with a more rapid root decay in the more diverse stands as well. In fact, fine roots of various tree species occurring in the DL 2 and DL 3 plots (in particular Fraxinus, Carpinus, and Acer) are characterized by higher nutrient concentrations and lower $\mathrm{C} / \mathrm{N}$ ratios than beech fine roots (Withington and others 2006; Meinen and others, unpublished).

\section{Fine-Root Production}

It has frequently been shown that estimates of fineroot production in forest ecosystems strongly depend on the chosen method (Aber and others 1985; Majdi 1996; Vogt and others 1998; Hertel and Leuschner 2002; Majdi and others 2005; Hendricks and others 2006; Gaul and others 2009). To reach the goals of this study, that is, to estimate fine-root production along the species-diversity gradient for each tree species separately, we decided to use a combination of two independent methods, which allow for species identification at the fine root level. The 'minimum-maximum' calculation based on the data from the labor-intensive sequential coring method gave roughly three times larger annual fine-root production estimates for the two mixed stands (DL 2c and DL 3a) than for the beechdominated DL la stand (about 500 and about 560 vs. $180 \mathrm{~g} \mathrm{~m}^{-2} \mathrm{y}^{-1}$ ). The fine-root production values obtained with the ingrowth core approach conducted at all 12 plots were markedly lower, but also showed a significant increase with tree species diversity from approximately $70 \mathrm{~g} \mathrm{~m}^{-2} \mathrm{y}^{-1}$ (DL 1 plots) to approximately $170 \mathrm{~g} \mathrm{~m}^{-2} \mathrm{y}^{-1}$ (DL 3 plots). The root production estimates obtained with the two approaches range in the lower and middle sections of fine-root production data given by Nadelhoffer and Raich (1992) for forest ecosystems in a global survey $\left(25-820 \mathrm{~g} \mathrm{~m}^{-2} \mathrm{y}^{-1}\right)$. A preliminary review of available literature data on fine-root production estimates for mixed temperate forests revealed a similar range (approximately 50$900 \mathrm{~g} \mathrm{~m}^{-2} \mathrm{y}^{-1}$; data from McClaugherty and others 1982; Hendrick and Pregitzer 1993; Aber and others 1985; Burke and Raynal 1994; Hertel and Leuschner 2002). Most of the cited studies used the sequential coring approach. Hendrick and Pregitzer (1993) used the minirhizotron approach, a method that is often assumed to produce more reliable data than other approaches (Johnson and others 2001; Majdi and others 2005; Hendricks and others 2006), and obtained very high fine root production estimates for two broad-leaved forests (730 and $\left.800 \mathrm{~g} \mathrm{~m}^{-2} \mathrm{y}^{-1}\right)$. In our study, the differences in root production estimates of the ingrowth core and sequential coring approaches may have been caused by the different root fractions included in the respective analysis. In the case of the ingrowth core approach, only living and dead root fragments of larger size (>10 mm length) are considered, whereas the sequential coring analysis also includes smaller fractions of dead root material that account for a large proportion of the fine-root necromass. The seasonal variation of fine-root necromass, which results from fluctuations in root mortality and root decay, is much more pronounced than that of fine-root biomass, as is particularly evident in the two species-rich DL 2 and DL 3 plots. Hence, one may speculate that the low root production estimates obtained from the ingrowth core approach might be due to an underestimation of seasonal changes in the dead fineroot fraction. The much larger seasonal fluctuation in fine root necromass in the DL 2 and DL 3 plots is most likely a reflection of more rapid root decay in these stands with higher $\mathrm{pH}$ values; these dynamics are neglected by the ingrowth core approach.

Although the absolute numbers of the fine-root production estimates may be questionable, the trend for higher production rates in the species-rich stands is supported by the results of both approaches. We are aware of only two studies comparing fine-root production in pure and mixed cultures of woody plants. In contrast to our results, McKay and Malcolm (1988) reported fine-root production about twice as high in pure stands of spruce and pine as compared to mixtures of these species. On the other hand, results of Fredericksen and Zedaker (1995) were in agreement with our results by observing a higher fine-root production in mixtures of loblolly pine and black locust saplings than in pure stands of these species. Why the species-rich stands in our study had markedly higher fine-root productions remains unclear. Both approaches indicate a shorter mean root lifespan in the more species-rich stands, a conclusion which needs confirmation by direct observation with minirhizotron tubes. Thus, further investigations using advanced methods of quantifying fine-root production in mixed stands are needed to answer the question as to whether belowground productivity of forests is enhanced by tree species diversity and what mechanisms are causing a putative belowground overyielding effect. 


\section{Fine-Root System Recovery After Disturbance}

Ingrowth cores were developed as an approach for estimating fine-root growth in a simple and repeatable manner (for example, Persson 1979, 1983; Vogt and others 1998; Makkonen and Helmisaari 1999; Jentschke and others 2001). However, this method introduces a major disturbance to the rhizosphere upon core installation, and thus often yields biased root production estimates (Powell and Day 1991; Makkonen and Helmisaari 1999; Hertel and Leuschner 2002; Ostonen and others 2005). On the other hand, this disturbance may represent a well-defined, replicated experiment to analyze the local regrowth of the tree species' fine-root system and thus may serve as a measure of the root system's ability to recover after disturbance. Our ingrowth core experiment with 30 cores per plot (in total 360 cores), which were exposed for 24 months, showed a significant increase in the rate of fine-root ingrowth into the cores from $72 \mathrm{~g} \mathrm{~m}^{-2} \mathrm{y}^{-1}$ in the monospecific DL 1 plots to $167 \mathrm{~g} \mathrm{~m}^{-2} \mathrm{y}^{-1}$ in the species-rich DL 3 plots, that is, a more than twice as rapid ingrowth when a higher number of species were present as roots in the soil compared to soils with only one root species. The recovery rate of fine-root biomass in the cores increased significantly from $0.26 \mathrm{y}^{-1}$ in the DL 1 plots to $0.51 \mathrm{y}^{-1}$ in the species-rich DL 3 plots. We interpret these results as evidence in support of the insurance hypothesis of biodiversity in the sense that a forest with a higher tree diversity recovers more rapidly in its fine-root system after a topsoil disturbance. However, an alternative explanation of different root ingrowth rates, which refers to differences in soil chemistry, also has to be considered. Soil $\mathrm{pH}\left(\mathrm{H}_{2} \mathrm{O}\right)$ was about 1.0 to 1.5 units lower in the monospecific DL 1 stands than in the DL 2 and DL 3 stands, which is thought to be mainly a consequence of the higher acidification potential of beech leaves (Hagen-Thorn and others 2004; Guckland and others 2009). Thus, it could be that effects of soil acidity or lower soil fertility on root growth are interfering with diversity effects on fine-root growth in our study. However, most studies investigating fine-root productivity along soil acidity or soil fertility gradients have not found a decrease in fine-root productivity with increasing acidity or decreasing nutrient availability, but rather an increase in fine-root production (Aber and others 1985; Côtè and others 1998; Hertel 1999; Jentschke and others 2001; Godbold and others 2003). Thus, it appears that the different root growth rates in the ingrowth cores of our study are mainly a consequence of the diversity gradient and not of the acidity gradient.

A higher capability for fine-root recovery may be relevant for various types of topsoil disturbances that occur irregularly in forests, for example, uprooting of trees, through the foraging activity of wild boar, or by logging activities. We assume that species-rich forests are able to recolonize disturbed, root-free soil patches more rapidly than speciespoor stands. Different phenologies of fine-root growth for the five species as observed in the studied forest stands could be one reason for a faster recovery in more diverse tree root systems. In the case of the herb root response, we assume that the sparse cover of the herb layer in the DL 1 plots retarded the root ingrowth as compared to the DL 2 and DL 3 plots with a richer herb layer.

\section{ACKNOWLEDGEMENTS}

This study was conducted in the context of Graduiertenkolleg 1086 'The role of biodiversity for biogeochemical cycles and biotic interactions in temperate deciduous forests'. We thank the National Park administration for the permission to perform the study in the Hainich National Park and for funding by the German Research Council (DFG). We thank all participants of the Graduiertenkolleg for excellent teamwork. Data on forest stand characteristics were kindly provided by Mascha Brauns, Anja Guckland, Inga Krämer, Andreas Mölder and Inga Schmidt.

\section{OPEN ACCESS}

This article is distributed under the terms of the Creative Commons Attribution Noncommercial License which permits any noncommercial use, distribution, and reproduction in any medium, provided the original author(s) and source are credited.

\section{REFERENCES}

Aber JD, Melillo JM, Nadelhoffer KJ, McClaugherty CA, Pastor J. 1985. Fine root turnover in forest ecosystems in relation to quantity and form of nitrogen availability: a comparison of two methods. Oecologia 66:317-21.

Andren O, Rajkai K, Katterer T. 1991. A nondestructive technique for studies of root distribution in relation to soil-moisture. Agric Ecosyst Environ 34:269-78.

Bartelink HH, Olsthoorn AFM. 1999. Mixed forest in western Europe. In: Olsthoorn AFM, Bartelink HH, Gardiner JJ, Pretzsch H, Hekhuis HJ, Franc A, Eds. Management of mixedspecies forest: silviculture and economics. Wageningen: IBN Scientific Contributions. pp 9-16. 
Burke MK, Raynal DJ. 1994. Fine root growth phenology, production, and turnover in a northern hardwood forest ecosystem. Plant Soil 162:135-46.

Chapin FS, Zavaleta ES, Eviner VT, Naylor RL, Vitousek PM, Reynolds HL, Hooper DU, Lavorel S, Sala OE, Hobbie SE, Mack MC, Diaz S. 2000. Consequences of changing biodiversity. Nature 405:234-42.

Côtè B, Hendershot WH, Fyles JW, Roy AG, Bradley R, Biron PM, Courchesne F. 1998. The phenology of fine root growth in a maple-dominated ecosystem: relationship with some soil properties. Plant Soil 201:59-69.

DeAngelis DL, Gardner RH, Shugart HH. 1981. Productivity of forest ecosystems studies during IBP: the woodland data set. In: Reichle DE, Ed. Dynamic properties of forest ecosystems. Cambridge: Cambridge University Press. pp 567-659.

Dornbush ME, Isenhart TM, Raich JW. 2001. Quantifying fineroot decomposition: an alternative to buried litterbags. Ecology 83:2985-90.

Fitter A. 1996. Characteristics and functions of root systems. In: Weisel Y, Eshel A, Kafkafi U, Eds. Plant roots: the hidden half. New York: Dekker. pp 1-20.

Fredericksen TS, Zedaker SM. 1995. Fine root biomass, distribution, and production in young pine-hardwood stands. New Forests 10:99-110.

Gaul D, Hertel D, Borken W, Matzner E, Leuschner C. 2008. Effects of experimental drought on the fine root system of mature Norway spruce. For Ecol Manag 256:1151-9.

Gaul D, Hertel D, Leuschner C. 2009. Estimating fine root longevity in a temperate Norway spruce forest using three independent methods. Funct Plant Biol 36:1-9.

Godbold DL, Fritz HW, Jentschke G, Meesenburg H, Rademacher P. 2003. Root turnover and root necromass accumulation of Norway spruce (Picea abies) are affected by soil acidity. Tree Physiol 23:915-21.

Guckland A, Jacob M, Flessa H, Thomas FM, Leuschner Ch. 2009. Acidity, nutrient stocks and organic-matter content in soils of a temperate deciduous forest with different abundance of European beech (Fagus sylvatica L.). J Plant Nutri Soil Sci 172:500-11.

Hagen-Thorn A, Callesen I, Armolaitis K, Nihlgård B. 2004. The impact of six European tree species on the chemistry of mineral topsoil in forest plantations on former agricultural land. For Ecol Manag 195:373-84.

Hector A. 2001. Biodiversity and functioning of grassland ecosystems: multi-site comparison. In: Kinzig AP, Tilman D, Pacala SW, Eds. The functional consequences of biodiversity: empirical progress and theoretical extensions. Princeton: Princeton University Press. pp 71-95.

Hector A, Schmid B, Beierkuhnlein C, Caldeira MC, Diemer M, Dimitrakopoulos PG, Finn JA, Freitas H, Giller PS, Good J, Harris R, Högberg P, Huss-Danell K, Joshi J, Jumpponen A, Körner C, Leadley PW, Loreau M, Minns A, Mulder CPH, O'Donovan G, Otway SJ, Pereira JS, Prinz A, Read DJ, Scherer-Lorenzen M, Schulze ED, Siamantziouras ASD, Spehn EM, Terry AC, Troumbis AY, Woodward FI, Yachi S, Lawton JH. 1999. Plant diversity and productivity experiments in European grasslands. Science 286:1123-7.

Hendrick RL, Pregitzer KS. 1993. The dynamics of fine-root length, biomass, and nitrogen-content in two northern hardwood ecosystems. Can J For Res 23:2507-20.

Hendricks JJ, Hendrick RL, Wilson CA, Mitchell RJ, Pecot SD, Guo DL. 2006. Assessing the patterns and controls of fine root dynamics: an empirical test and methodological review. J Ecol 94:40-57.

Hertel D. 1999. Das Feinwurzelsystem von Rein- und Mischbeständen der Rotbuche: Struktur, Dynamik und interspezifische Konkurrenz. Stuttgart: Dissertationes Botanicae 317. p 190.

Hertel D, Leuschner C. 2002. A comparison of four different fine root production estimates with ecosystem carbon balance data in a Fagus-Quercus mixed forest. Plant Soil 239:237-51.

Hölscher D, Hertel D, Leuschner C, Hottkowitz M. 2002. Tree species diversity and soil patchiness in a temperate broadleaved forest with limited rooting space. Flora 197:118-25.

IUSS Working Group WRB. 2006. World reference base for soil resources 2006. World Soil Resource Reports, vol. 103. Rome: FAO.

Jacob M, Weland N, Platner C, Schaefer M, Leuschner Ch, Thomas FM. 2009. Nutrient release from decomposing leaf litter of temperate deciduous forest trees along a gradient of increasing tree species diversity. Soil Biol Biochem. doi:10.1016/j.soilbio.2009.07.024.

Jentschke G, Drexhage M, Fritz HW, Fritz E, Schella B, Lee DH, Gruber F, Heimann J, Kuhr M, Schmidt J, Schmidt S, Zimmermann R, Godbold DL. 2001. Does soil acidity reduce subsoil rooting in Norway spruce Picea abies? Plant Soil 237:91-108.

Johnson MG, Tingey DT, Phillips DL, Storm MJ. 2001. Advancing fine root research with minirhizotrons. Environ Exp Bot 45:263-89.

Joslin JD, Henderson GS. 1987. Organic matter and nutrients associated with fine root turnover in a White oak stand. For Sci 33:330-46.

Kelty MJ. 1992. Comparative productivity of monocultures and mixed stands. In: Kelty MJ, Larson BC, Oliver CD, Eds. The ecology and silviculture of mixed-species forests. Dordrecht: Kluwer. pp 125-41.

King JS, Lee Allen H, Dougherty P, Strain BR. 1997. Decomposition of roots in loblolly pine: effects of nutrient and water availability and root size on mass loss and nutrient dynamics. Plant Soil 195:171-84.

Konôpka B, Noguchi K, Sakata T, Takahashi M, Konôpkova Z. 2006. Fine root dynamics in a Japanese cedar Cryptomeria japonica plantation throughout the growing season. For Ecol Manag 225:278-86.

Korn S. 2004. Experimentelle Untersuchung der Wasseraufnahme und der hydraulischen Eigenschaften des Wurzelsystems von sechs heimischen Baumarten. PhD thesis, University of Göttingen.

Leuschner C, Hertel D, Coners H, Büttner V. 2001. Root competition between beech and oak: a hypothesis. Oecologia 126:276-84.

Leuschner C, Jungkunst HF, Fleck S. 2009. Functional role of forest diversity: pros and cons of synthetic stands and acrosssite comparisons in established forests. Basic Appl Ecol 10:1-9.

Loreau M, Hector A. 2001. Partitioning selection and complementarity in biodiversity experiments. Nature 412:72-6.

Lyr H. 1996. Effect of the root temperature on growth parameters of various European tree species. Ann Sci For 53:317-23.

Lyr H, Garbe V. 1995. Influence of root temperature on growth of Pinus sylvestris, Fagus sylvatica, Tilia cordata and Quercus robur. Trees-Struct Funct 9:220-3.

Magurran AE. 2004. Measuring biological diversity. Oxford: Blackwell Science. 
Majdi H. 1996. Root sampling methods-applications and limitations of the minirhizotron technique. Plant Soil 185:255-8.

Majdi H, Pregitzer KS, Moren AS, Nylund JE, Agren GI. 2005. Measuring fine root turnover in forest ecosystems. Plant Soil 276:1-8.

Makkonen K, Helmisaari HS. 1998. Seasonal and yearly variations of fine-root biomass and necromass in a Scots pine Pinus sylvestris L. stand. For Ecol Manag 102:283-90.

Makkonen K, Helmisaari HS. 1999. Assessing fine-root biomass and production in a Scots pine stand-comparison of soil core and root ingrowth core methods. Plant Soil 210:43-50.

McClaugherty CA, Aber JD, Melillo JM. 1982. The role of fine roots in the organic matter and nitrogen budgets of two forested ecosystems. Ecology 635:1481-90.

McClaugherty CA, Aber JD, Melillo JM. 1984. Decomposition dynamics of fine roots in forested ecosystems. Oikos 42:37886.

McKay HM, Malcolm DC. 1988. A comparison of the fine root component of a pure and a mixed coniferous stand. Can J For Res 18:1416-26.

Meinen C, Hertel D, Leuschner C. 2009. Biomass and morphology of fine roots in temperate broad-leaved forests differing in tree species diversity: Is there evidence of belowground overyielding? Oecologia (in press). doi:10.1007/ S00442-009-1352-7.

Mölder A, Bernhardt-Römermann M, Schmidt W. 2006. Forest ecosystem research in Hainich National Park Thuringia: first results on flora and vegetation in stands with contrasting tree species diversity. Waldoekologie Online 3:83-99.

Mölder A, Bernhardt-Römermann M, Schmidt W. 2008. Herblayer diversity in deciduous forests: Raised by tree richness or beaten by beech? For Ecol Manag 256:272-81.

Nadelhoffer KJ, Raich JW. 1992. Fine root production estimates and belowground carbon allocation in forest ecosystems. Ecology 73:1139-47.

Ostonen I, Lohmus K, Pajuste K. 2005. Fine root biomass, production and its proportion of NPP in a fertile middle-aged Norway spruce forest: comparison of soil core and ingrowth core methods. For Ecol Manag 212:264-77.

Persson H. 1978. Root dynamics in a young Scots pine stand in Central Sweden. Oikos 30:508-19.

Persson H. 1979. Fine-root production, mortality and decomposition in forest ecosystems. Vegetatio 41:101-9.

Persson H. 1980. Fine-root production, mortality and decomposition in forest ecosystems. Vegetatio 41:101-9.

Persson H. 1983. The distribution and production of fine roots in boreal forests. Plant Soil 71:87-101.

Peterson G, Allen CR, Holling CS. 1998. Ecological resilience, biodiversity, and scale. Ecosystems 1:6-18.

Powell SW, Day FP. 1991. Root production in four communities in the Great Dismal Swamp. Am J Bot 78:288-97.

Pretzsch H. 2005. Diversity and productivity in forests: evidence from long-term experimental plots. In: Scherer-Lorenzen M, Körner C, Schulze ED, Eds. Forest diversity and function: temperate and boreal systems, ecological studies. Berlin: Springer. pp 41-64.

Ruess RW, van Cleve K, Yarie J, Viereck LA. 1996. Contributions of fine root production and turnover to the carbon and nitrogen cycling in taiga forests of the Alaskan interior. Can J For Res 26:1326-36.
Scherer-Lorenzen M, Schulze ED, Don A, Schumacher J, Weller E. 2007. Exploring the functional significance of forest diversity: a new long-term experiment with temperate tree species BIOTREE. Perspect Plant Ecol Evol Syst 9:53-70.

Silver WL, Miya RK. 2001. Global patterns in root decomposition: comparisons of climate and litter quality effects. Oecologia 129:407-19.

Steele SJ, Gower ST, Vogel JG, Norman JM. 1997. Root mass, net primary production and turnover in aspen, jack pine and black spruce forests in Saskatchewan and Manitoba, Canada. Tree Physiol 17:577-87.

Teskey RO, Hinckley TM. 1981. Influence of temperature and water potential on root growth of white oak. Physiol Plant 52:363-9.

Tierney GL, Fahey TJ, Groffman PM, Hardy JP, Fitzhugh RD, Driscoll CT. 2001. Soil freezing alters fine root dynamics in a northern hardwood forest. Biogeochemistry 56:175-90.

Tilman D. 1999. Ecology-diversity and production in European grasslands. Science 286:1099-100.

Tilman D, Wedin D, Knops J. 1996. Productivity and sustainability influenced by biodiversity in grassland ecosystems. Nature 379:718-20.

Tilman D, Lehman CL, Thomson KT. 1997. Plant diversity and ecosystem productivity: theoretical considerations. Proc Natl Acad Sci USA 94:1857-61.

Tilman D, Reich PB, Knops J, Wedin D, Mielke T, Lehman C. 2001. Diversity and productivity in a long-term grassland experiment. Science 294:843-5.

Trumbore SE, Gaudinski JB. 2003. The secret lives of roots. Science 302:1344-5.

Tryon PR, Chapin FS. 1983. Temperature control over rootgrowth and root biomass in Taiga forest trees. Can J For Res 13:827-33.

van Praag HJ, Sougnezremy S, Weissen F, Carletti G. 1988. Root turnover in a beech and a spruce stand of the Belgian Ardennes. Plant Soil 105:87-103.

Vesterdal L, Schmidt IK, Callesen I, Nillson LO, Gundersen P. 2008. Carbon and nitrogen in forest floor and mineral soil under six common European tree species. For Ecol Manag 255:35-48.

Vogt KA, Edmonds RL, Grier CC. 1981. Seasonal changes in biomass and vertical distribution of mycorrhizal and fibroustextured conifer fine roots in 23- and 180-year-old subalpine Abies amabilis stands. Can J For Res 11:223-9.

Vogt KA, Vogt DJ, Palmiotto PA, Boon P, Ohara J, Asbjornsen H. 1996. Review of root dynamics in forest ecosystems grouped by climate, climatic forest type and species. Plant Soil 187:159-219.

Vogt KA, Vogt DJ, Bloomfield J. 1998. Analysis of some direct and indirect methods for estimating root biomass and production of forests at an ecosystem level. Plant Soil 200:71-89.

Withington JM, Reich PB, Oleksyn J, Eissenstat DM. 2006. Comparisons of structure and life span in roots and leaves among temperate trees. Ecol Monogr 76:381-97.

Xiao CW, Yuste JC, Janssens IA, Roskams P, Nachtergale L, Carrara A, Sanchez BY, Ceulemans R. 2003. Above- and belowground biomass and net primary production in a 73 year-old Scots pine forest. Tree Physiol 23:505-16. 